\title{
FDA panel sees problems with labelling of milk hormone
}

Washington. An advisory committee to the US Food and Drug Administration (FDA) appears to oppose the mandatory labelling of food products derived from dairy cows treated with a recombinant form of bovine growth hormone (rbGH), but Congress may take up the issue and it seems likely that opponents of rbGH will wage a campaign at the grocery store.

The committee last week held two days of public hearings on the question, which involves a hormone used to boost milk production in dairy cows. Although the committee stopped short of making formal recommendations to FDA, more than twothirds of its members spoke out against requiring mandatory labelling and said that an alternative would be voluntary labelling of products from cows not treated with the hormone provided FDA could authenticate such claims.

"I don't know that I got a real consensus out of it [the meeting]", says Gerald Guest, director of FDA's Center for Veterinary Medicine, "but I think people recognize the difficulty if you did label. I heard most people saying, 'Well, even if the government doesn't require it, voluntary labelling would be $O K$ ', and I think that's true."

The committee heard testimony from more than 50 individuals representing animal rights groups, biotechnology companies, consumer and citizen action groups, dairy farmers, environmentalists, members of Congress, physicians, trade associations and veterinarians. Although the debate, often heated, centred on whether foods derived from dairy cows supplemented with rbGH should be labelled as such, and if so why, the issue at times became blurred by those who oppose the use of rbGH for reasons outside the purview of FDA

Opponents say that special labelling is unwarranted and unprecedented and would have considerable implications for food labelling requirements generally. They argue that FDA does not have the authority to require labelling given that bGH occurs naturally in milk, that studies have found no discernible difference in trace levels of bGH before and after supplementation and that milk from supplemented cows and untreated cows is indistinguishable in terms of composition, quality, taste and texture. The situation is compounded by the practice of pooling milk from farms and by the lack of a practical and accurate method of distinguishing between rbGH and bGH that occurs normally in milk.

In 1992, the General Accounting Office issued a report suggesting that, although rbGH does not appear to represent a direct human food safety risk, FDA should with- hold approval until the question of indirect human food safety risks is resolved (see Nature 358, 614; 1992). An FDA veterinary medicine advisory committee last March declared that a statistically significant increase in mastitis (inflammation of the udder) in cows treated with rbGH was a "manageable risk" that would not lead to an increase in antibiotic residues in milk.

Proponents of labelling believe that FDA has underplayed the mastitis issue and argue that a "manageable" risk is a risk nonetheless and that consumer surveys indicate that people want to be given the choice of whether or not to purchase such products. "If the FDA gives the green light to unlabelled bGH products", says Jeremy Rifkin of the Pure Food Campaign, "we intend to defeat these products at the marketplace" with a sustained consumer boycott.

Although federal regulations prohibit the FDA from saying when and if rbGH might be approved, Guest did venture that he felt "it's very much a public policy issue more than a scientific issue now" and that Con-

gress might want to get involved.

Bovine growth hormone (also called bovine somatotropin, or bST) is a protein hormone produced in the pituitary gland of cattle that plays an important role in regulating the metabolism of carbohydrates, fats and proteins. It is one of 30 hormones known to be normally present in milk and is not biologically active in humans. Although it was shown in the 1930s that milk production in dairy cows could be increased by giving cows supplementary bGH injections, its commercial use was prevented by the limited supply of purified bGH derived from pituitary glands. With the advent of biotechnology, large quantities of biosynthetic bGH can now be produced using recombinant DNA technology and used to raise milk yields by an average of $10-15$ per cent.

Four companies - American Cyanamid, Elanco (a division of Eli Lilly \& Co.), Monsanto and Upjohn - are seeking FDA approval for their particular recombinant form of $b G H$. These products are either similar or identical (in the case of Upjohn's product, Somavubove) to the naturally occurring bGH variant containing 191 amino acids. The other three products differ in the amino acids that are substituted for the terminal alanine residue.

Diane Gershon

\section{Italian court wrestles with cold fusion suit}

Munich. An Italian judge trying to decide if cold-fusion advocates Stanley Pons and Martin Fleischmann were libelled by the daily newspaper La Repubblica has called in a technical adviser to help him understand the scientific aspects of their work, which created an international sensation when it was announced in 1989. The use of a technical adviser, a new procedure for Italy, is one of several novel features of the case, which is being tried in a country with no legal definition of scientific fraud.

In October 1991, Italian journalist Giovanni Pacci is alleged to have libelled British chemists Fleischmann and Pons by referring to them as scientific frauds in a strongly worded review of a new translation of Axel Kahn's book False Prophets. Pacci made an indirect reference to a group of

\section{IMAGE UNAVAILABLE FOR COPYRIGHT REASONS}

Pons and Fleischmann, right, with 1989 model.
Although they were not mentioned by name, Giuliano Preparata, Tullio Bressani and Emilio Del Giudice of the Institute of Physics in Milan believed that they were identifiable and requested a retraction. Instead La Repubblica published their letters along with a defiant commentary from Pacci. As a result, the Italians joined Fleischmann and Pons at the beginning of last year in suing the influential newspaper for IL8 billion (US\$5 million), an unusual action in a country where such lawsuits are rare.

The case itself does not address the issue of cold fusion, but rather whether the scientists can justly be accused of fraud. Even so, the judge decided to obtain an independent assessment of the 105 'pieces of scientific evidence' submitted by the plaintiffs and appointed Giovanni Licheri, a physical chemist from the University of Cagliari in Sardinia, to tell him whether the data could have been fraudulently reported.

Licheri has six months to form an opinion on the scientific validity of the work, a point of rancorous debate for two years after the initial announcement in March 1989. A first meeting took place on 28 April involving Licheri, the five scientists who filed the lawsuit and Douglas Morrison of CERN, who was chosen as a scientific adviser by $L a$ Repubblica. Morrison publishes an electronic mail newsletter that takes a sceptical view of cold fusion. 